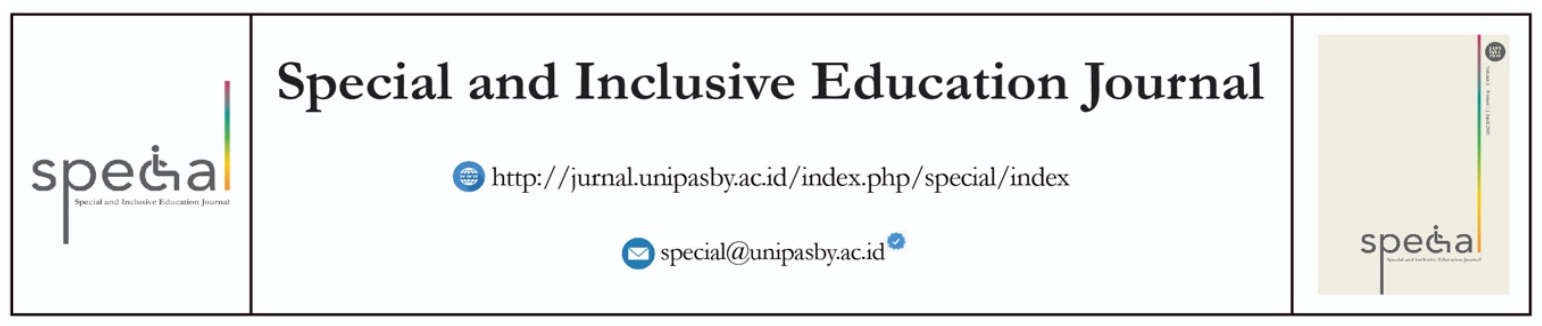

\title{
Penguatan Aksesibilitas Model Blended Learning pada Matakuliah Bahasa Indonesia bagi Mahasiswa Tunarungu dan Tunanetra
}

\author{
Arsy Anggrellanggi, Mahardika Supratiwi, Munawir Yusuf, Subagya, Tias Martika \\ arsy@staff.uns.ac.id $\mid$ mahardika.s@staff.uns.ac.id $\mid$ munawiryusuf@staff.uns.ac.id $\mid$ \\ subagya60@staff.uns.ac.id | tiasmartika uns@staff.uns.ac.id
}

Pendidikan Khusus - Universitas Sebelas Maret

Jl. Ir. Sutami No.36 A, Pucang sawit, Kec. Jebres, Kota Surakarta, Jawa Tengah 57126

\section{Artikel Info}

Koresponden penulis :

Arsy Anggrellanggi

arsy@staff.uns.ac.id

- Diterima 21 Desember 2019

- Direview 20 Januari 2020

- Disetujui 2 April 2020

- Dipublikasi 29 April 2020

Kata Kunci:

Aksesibilitas; Blended

Learning; Bahasa Indonesia;

Tunarungu; Tunanetra

\section{Keywords:}

Accessibility; Blended

Learning; Indonesian; Deaf;

Blind

\begin{abstract}
Absstrak
Penelitian ini bertujuan 1) mengetahui pengaruh blended learning terhadap penguasaan materi Bahasa Indonesia, 2) mengetahui respons mahasiswa tunarungu dan tunanetra terhadap pemanfaatan aksesibilitas dalam blended learning. Penelitian ini menggunakan rancangan penelitian mix method. Untuk mengetahui pengaruh blended learning digunakan Randomized Posttest only Control Group Design. Populasinya adalah mahasiswa semester 3 Pendidikan Khusus Universitas Sebelas Maret dan sampelnya yaitu kelas A sebagai kelas eksperimen, kelas B sebagai kelas kontrol. Untuk mengetahui respons mahasiswa tunarungu dan tunanetra melalui metode observasi, wawancara, dan dokumentasi. Hasil uji $\mathrm{t}$ penguasan materi didapat thitung $=6,64>=$ ttabel $=1,66$, menunjukkan ada perbedaan, sedangkan untuk uji lanjut yaitu uji Tuckey menunjukkan Qhitung $=7,55>$ Qtabel $=2,85$, menunjukan bahwa penguasaan materi mahasiswa yang menggunakan blended learning lebih tinggi daripada konvensional. Respons mahasiswa terhadap penggunaan blended learning dalam mata kuliah bahasa Indonesia berdasarkan hasil observasi sangat aktif, wawancara cukup baik, dan dokumentasi sangat baik. Simpulan penelitian ini adalah 1) ada pengaruh blended learning terhadap penguasaan materi Bahasa Indonesia, 2) respons mahasiswa tunarungu dan tunanetra sangat baik.

Abstarct
This study aims to 1) determine the effect of blended learning on of
Indonesian language material, 2) determine the response of deaf and blind
students to the use of accessibility in blended learning. This study uses a
mix method research design. To determine the effect of blended learning
Randomized Posttest only Control Group Design is used. The population
is the 3rd semester students of Universitas Sebelas Maret on Special
Education departement and the sample is class A as an experimental class,
class B as a control class. To determine the response of deaf and blind
students through observation, interviews, and documentation. The results
of the test t mastery of the material obtained thitung $=6.64>=$ ttable $=$
1.66, showed no difference, while for further tests namely the Tuckey test
showed Qcount $=7.55>$ Qtable $=2.85$, indicating that the mastery of
material students who use Blended learning is higher than conventional.
Student responses to the use of blended learning in Indonesian language
courses based on the results of very active observations, good enough
interviews, and very good documentation. The conclusions of this study
are 1) there is the influence of blended learning on mastering Indonesian
material, 2) Good response deaf and blind student
\end{abstract}




\section{PENDAHULUAN}

Pengertian pembelajaran atau learning adalah suatu proses yang dilakukan peserta didik untuk mencapai sasaran belajarnya. Agar peserta didik dapat mencapai sasaran belajar secara optimal, maka peserta didik perlu menambah waktu belajar di luar kelas untuk membaca, menulis, diskusi dengan peserta didik lainnya, menyelesaikan soal-soal, dan lain-lain. Selanjutnya, skenario pembelajaran formal di kelas menjadi belajar bersifat informal, terjadi di tempat-tempat yang tak terduga dan pada waktu yang tidak terduga.

Proses belajar mengajar hakikatnya adalah proses penyampaian pesan dari pengantar ke penerima. Daryanto (2013: 5) menyatakan pesan dalam pembelajaran berupa isi ajaran yang dituangkan ke dalam simbol-simbol komunikasi, baik verbal (kata-kata dan tulisan) maupun nonverbal, proses ini dinamakan encoding. Dengan demikian, pembelajaran merupakan suatu komunikasi, maka untuk mempermudah dalam menyampaikan pesan diperlukan sebuah akses yang memadahi bagi semua penerima pesan.

Komunikasi dapat dilakukan dalam berbagai bentuk, salah satunya melalui internet. Komunikasi melalui internet bisa dilakukan secara interpersonal (misalnya e-mail dan chattting) atau secara massal, yang dikenal one to many communication (misalnya mailing list). Menurut Prakoso (2005: 34) teknologi internet mengemuka sebagai media yang multirupa. Internet juga mampu hadir secara real time audio visual seperti pada metode konvensual dengan adanya aplikasi teleconference. Berdasarkan hal tersebut perkembangan teknologi telah membawa manusia pada ruang yang mampu memberikan kemudahan dalam kesehariannya. Hal yang paling sederhana adalah mempermudah komunikasi baik secara individu maupun secara berkelompok. Kemudahan tersebut juga mulai meramban pada bidang pendidikan.

Pendidikan pada umumnya semakin berkembang dengan adanya teknologi. Teknologi akan memberikan keleluasaan kepada pendidik dalam memberikan materi kepada peserta didik. Dengan memanfaatkan teknologi pendidik akan mampu menerapkan strategi pembelajaran yang lebih baik, sehingga pendidik menjadi lebih kreatif, inovatif, dan berkualitas. Untuk menjawab tantangan pada dunia pendidikan tersebut diperlukan teknologi yang dapat menyediakan pendidikan dengan metode yang lebih efektif, cepat dan persiapannya lebih singkat. Salah satu implementasi teknologi tersebut adalah e-learning. E-learning merupakan terobosan baru dalam dunia pendidikan.

Gilbertdan Jones (2001) serta Michael (2013) (dalam Wahyuningsing dan Makmur, 2017: 3) mengemukakan bahwa "e-learning merupakan segala bentuk aktivitas pembelajaran yang memanfaatkan media elektronik untuk belajar. Daryanto (2013: 168) menyatakan bahwa e-learning merupakan sistem pembelajaran yang memanfaatkan media elektronik sebagai alat untuk membantu kegiatan pembelajaran. Berdasarkan pandangan tersebut dapat disimpulkan, e-learning merupakan pembelajaran dengan menggunakan jasa bantuan perangkat elektronika seperti komputer maupun internet. Mubaraq (2009) menyatakan pembelajaran berbasis web mampu menumbuhkan kemandirian siswa untuk mengkonstruksi sendiri pengetahuannya, ditunjukkan dengan adanya 
peningkatan penguasaan konsep, peningkatan generik sains dan siswa memberikan tanggapan yang baik. Nuraeni dkk (2007), menunjukkan bahwa pemanfaatan multimedia dalam pembelajaran dapat meningkatkan penguasaan konsep dan motivasi siswa. Mahasiswa berkebutuhan khusus merupakan mahasiswa yang memiliki hambatan motorik, visual dan auditori dan hambatan lain tanpa disertai hambatan intelegensi di perguruan tinggi (Jauhari \& Dewi, 2019)

Dalam pelaksanaannya, e-learming menggunakan jasa audio, video atau perangkat komputer atau kombinasi dari ketiganya. E-learning merupakan suatu kemajuan penting dalam sistem pendidikan modern. Penggunaan e-learning pada pembelajaran telah terbukti memberikan keuntungan dalam pembelajaran. Effendi dan Zhuang (2005: 9) memaparkan beberapa kelebihan yang ditawarkan elearning yaitu: (1) dari segi biaya, (2) fleksibilitas waktu, (3) fleksibilitas tempat, (4) fleksibilitas kecepatan pembelajaran, (5) standarisasi pengajaran, (6) efektivitas pengajaran, (7) kecepatan distribusi, (8) ketersediaan on-demand, dan (9) otomatis proses administrasi.

UNS telah melaksanakan e-learning sejak tahun 2015, dimana dosen wajib mengunggah RPS pada laman ocw.uns.ac.id. Namun penggunaannya masih sebatas itu saja, sedangkan dalam pemanfaatan e-learning pada kegiatan pembelajaran masih belum banyak dilakukan. Pada tahun 2019, dosen pengguna e-learning hanya berkisar 4\% dari total 1.780 dosen. Hal ini membuat aksesibilitas pembelajaran bagi mahasiswa disabilitas kurang terpenuhi.

Kegiatan pembelajaran di UNS masih bersifat teacher centered. Untuk itu perlu diubah paradigma pembelajaran menuju ke pembelajaran student center, salah satu model pembelajaran yang bersifat student center adalah pembelajaran blended learning. Blended learning yaitu pembelajaran yang mengkombinasikan pembelajaran tatap muka dengan pembelajaran online.

Menurut Rahayu \& Nuryata (2010) bahwa blended learning mengkombinasikan metode pendidikan konvensional (tatap muka) dengan pembelajaran yang ditunjang dengan adanya teknologi. Dengan blended learning penguasaan konsep mahasiswa lebih baik. Bawaneh (2011) menyatakan bahwa blended learning dapat meningkatkan performansi peserta didik. Hal ini dapat dilihat dari meningkatnya jumlah mahasiswa yang online dalam pembelajaran, serta melakukan diskusi online. Blended learning yang mengkombinasikan metode tatap muka dan e-learning dapat melibatkan mahasiswa secara aktif dan memungkinkan mahasiswa mendapat umpan balik. Senada dengan hal ini Mujiyanto (2012) menyatakan bahwa blended learning memiliki kelebihan yaitu siswa memiliki banyak waktu belajar dibawah bimbingan oleh dosen.

Sedangkan bagi mahasiswa disabilitas, mereka akan sangat terbantu. Mengingat tunanetra dapat menggunakan speech reader dan tunarungu dapat mempersiapkan diri dengan speech to text. Namun di UNS akses teknologi tersebut belum mewadahi kebutuhan siswa karena belum banyak dosen yang sadar dengan kebutuhan pembelajaran mereka. Berdasarkan berbagai hal tersebut, penting dilakukan 
penelitian mengenai penerapan Penguatan Aksesibilitas Model Blended Learning pada Matakuliah Bahasa Indonesia bagi Mahasiswa Tunarungu dan Tunanetra.

\section{METODE PENELITIAN}

Penelitian ini menggunakan rancangan penelitian mix method. Untuk mengetahui pengaruh blended learning digunakan Randomized Posttest only Control Group Design. Populasinya adalah mahasiswa semester 3 Pendidikan Khusus Universitas Sebelas Maret dan sampelnya yaitu kelas A sebagai kelas eksperimen, kelas B sebagai kelas kontrol. Untuk mengetahui respons mahasiswa tunarungu dan tunanetra melalui metode observasi, wawancara, dan dokumentasi. Dalam penelitian ini instrumen yang digunakan adalah instrumen berupa soal tes berbentuk obyektif untuk mengukur penguasaan materi Bahasa Indonesia. Data hasil penelitian eksperimen dianalisis dengan menggunakan uji t dengan menguji signifikansi perbedaan penguasaan materi, kemudian dilanjutkan dengan uji Tukey untuk melihat perbandingan penguasaan materi setelah dilakukan pembelajaran.

Tabel 1. Tabel Randomized Posttest only Control Group Design

\begin{tabular}{ccc}
\hline Group & Perlakuan & Post-test \\
\hline Ekperimen & $\mathrm{X}$ & $0_{1}$ \\
\hline Kontrol & & $0_{2}$ \\
\hline
\end{tabular}

\section{HASIL DAN PEMBAHASAN}

Hasil uji hipotesis yang menyatakan penguasaan materi mahasiswa yang belajar menggunakan blended learning lebih tinggi dibandingkan penguasaan konsep peserta didik yang belajar tanpa menggunakan blended learning disajikan pada tabel berikut.

Tabel 2. Hasil penelitian

\section{Tabel 2}

\begin{tabular}{lccc}
\hline Kelas yang diuji & $\mathrm{Db}$ & $\mathrm{t}_{\text {Hitung }}$ & $\mathrm{t}_{\text {Tabel }}$ \\
\hline $\mathrm{A}-\mathrm{B}$ & 92 & 6,44 & 1,66 \\
\hline
\end{tabular}

Tabel 3

\begin{tabular}{lccc}
\hline Kelas yang diuji & Dk & $Q_{\text {Hitung }}$ & $Q_{\text {Tabel }}$ \\
\hline A-B & $Q_{(0,05 ; \% ; 6)}$ & 7,55 & 2,85 \\
\hline
\end{tabular}

Tabel 4

\begin{tabular}{llll}
\hline Kelas yang diuji & $\mathrm{Db} \mathrm{t}_{\text {Hitung }}$ & $\mathrm{t}_{\text {Tabel }}$ \\
\hline $\mathrm{A}-\mathrm{B}$ & 92 & 2,65 & 1,66 \\
\hline
\end{tabular}

Tabel 5

\begin{tabular}{lll}
\hline Kelas yang diuji $D k$ & $Q_{\text {Hitung }} Q_{\text {Tabel }}$ \\
\hline$A-B \quad Q_{(0.05: 2 ; 46)}$ & 3,19 & 2,85 \\
\hline
\end{tabular}

Tabel 2 menunjukkan bahwa tHitung $=6,44>$ tTabel $=$ 1,66 dengan taraf signifikansi 0,05, maka ada perbedaan penguasaan konsep fisika kelas eksperimen dengan penguasaan konsep fisika kelas kontrol. 
Tabel 3 menunjukkan bahwa QHitung $=7,55>$ QTabel $=$ 2,85 dengan taraf signifikansi 0,05, maka hipotesis yang menyatakan penguasaan konsep fisika peserta didik yang belajar menggunakan blended learning lebih tinggi dibandingkan penguasaan konsep fisika peserta didik yang belajar tanpa menggunakan blended learning diterima.

Tabel 4 menunjukkan bahwa tHitung $=2,65>$ tTabel $=1,66$ dengan taraf signifikansi 0,05 , maka ada perbedaan penalaran fisika kelas eksperimen dengan penalaran fisika kelas kontrol.

Tabel 5 menunjukkan bahwa QHitung $=3,19>$ QTabel $=$ 2,85 dengan taraf signifikansi 0,05, maka hipotesis yang menyatakan penalaran fisika peserta didik yang belajar menggunakan blended learning lebih tinggi dibandingkan penalaran fisika peserta didik yang belajar tanpa menggunakan blended learning diterima.

Dengan blended learning ini penguasaan materi mahasiswa lebih baik hal ini terlihat dari penguasaan materi pada kelas eksperimen lebih tinggi daripada penguasaan materi kelas kontrol, ini dikarenakan informasi yang mahasiswa dapatkan jauh lebih banyak daripada informasi yang diberikan oleh dosen serta dalam bentuk bermacam-macam dan selalu up to date. Hal ini sesuai dengan penelitian yang dilakukan oleh Munawar (2011) tentang model blended learning yang menggabungkan pembelajaran tatap muka dikelas dengan pembelajaran berbasis web terbukti dapat meningkatkan pemahaman siswa kelas X SMA dalam mata pelajaran fisika, dan Suhendi (2009), bahwa e-learning dapat meningkatkan pemahaman siswa dan penguasaan konsep serta memperbaiki sikap belajar mahasiswa pada materi pencemaran lingkungan. Senada dengan Kara dan Harun Yakar dalam Husni dkk (2010) menyatakan penggunaan komputer dalam pengajaran dapat meningkatkan pemahaman konsep mahasiswa serta kemampuan individu mendapatkan informasi di masyarakat. Bantala (2010) menyimpulkan bahwa pembelajaran menggunakan e-learning terbukti dapat meningkatkan kemampuan kognitif peserta diklat teknik jaringan komputer dasar.

Pada blended learning informasi yang didapat oleh mahasiswa lebih banyak dan dari berbagai sumber. Dengan mendapat informasi lebih mereka mampu menyelesaikan permasalahan, menganalisis, membandingkan dengan kecukupan informasi yang mereka dapat. Informasi atau materi yang ada dalam pembelajaran online antara lain dalam bentuk teks, gambar, video, simulasi, partisipasi dalam diskusi, dan mengemukakan pendapat.

\section{KESIMPULAN}

Berdasarkan analisis hasil penelitian dan pembahasan, maka dapat diketahui: 1) Penguasaan materi mahasiswa yang belajar menggunakan blended learning lebih tinggi dibandingkan penguasaan materi mahasiswa yang belajar tanpa menggunakan blended learning; 2) Respons mahasiswa terhadap penggunaan blended learning dalam mata kuliah bahasa Indonesia berdasarkan hasil observasi sangat aktif, wawancara cukup baik, dan dokumentasi sangat baik. Sehingga simpulan penelitian ini adalah 1) ada pengaruh blended learning terhadap penguasaan materi Bahasa Indonesia, 2) respons mahasiswa tunarungu dan tunanetra sangat baik. 


\section{DAFTAR PUSTAKA}

Bantala, A.P. 2010. Penerapan E-Learning (Learn-ing Management System) untuk Mening-katkan Kemampuan Kognitif Peserta Diklat Teknik Jaringan Komputer Dasar di PPPPTK Bmti Bandung. Tesis Jurusan Pendidikan Teknologi dan Kejuruan UPI. Bandung: PPs UPI.

Bawaneh, S.S. 2011. The Effects Of Blended Learn-ing Approach On Students' Performance: Evidence From A Computerized Accounting Course. Interdisciplinary Journal of Research in Business Vol. 1, Issue. 4, April 2011.p 43-50.

Daryanto. 2010. Media Pembelajaran. Yogyakarta: Gava Media.

Effendi, Empy dan Hartono Zhuang. 2005. E- learning Konsep dan Aplikasi.Yogyakarta: C.V. Andi Offset.

Husni, A., Juanda, E.A. \& Hamidah, I. 2010. Model Pembelajaran Kooperatif Berbantuan Web Pada Materi Fluida Statis Untuk Mening-katkan Pemahaman Konsep Siswa SMA.Prosiding Seminar Nasional Fisika 2010. p 451-458.

Jauhari, M. N., \& Dewi, D. P. (2019). Pelaksanaan Cooperative Learning Model Pada Mata Kuliah Media Pembelajaran Abk Bagi Mahasiswa Berkebutuhan Khusus Prodi Pendidikan Khusus Fkip Universitas Pgri Adibuana Surabaya. Buana Pendidikan: Jumal Fakultas Keguruan Dan Ilmu Pendidikan, 15(27), 79-89.

Mujiyanto. 2012. Pengaruh Model Blended Learn-ing terhadap Pemahaman Konsep Ditinjau dari Penalaran Formal Siswa Kelas X SMA Negeri 1 Balikpapan. Thesis tidak diterbitkan, Malang: PPs UM.

Munawar, D.H,2011. Efektivitas Model Blended Learning Dengan Moodle Dalam Meningkat-kan Hasil Belajar Siswa Pada Mata Pelaja-ran Fisika..Tesis Jurusan Pengembangan Kurikulum UPI Bandung. Bandung: PPs UPI.

Rahayu, E.S., \& Nuryata, I.M. 2010. Pembelajaran Masa Kini. Jakarta: Sekarmita Training pub-lishing. Suhendi. 2009. Implementasi E-Learning Untuk Me-ningkatkan Penguasaan Konsep dan Memperbaiki Sikap Belajar Mahasiswa Pada Ma-teri Pencemaran Lingkungan. Tesis Jurusan Pendidikan IPA UPI Bandung. Bandung: PPs UPI.

Wahyuningsih, Dian dan Rakhmat Makmur.2017. E-learning Teori dan Aplikasi.Bandung: Informatika Bandung. 